\title{
Medical Risk Assessment in Dental Patients: A Cross Sectional KAP[Knowledge, Attitude And Practice] Study Among Dental Practitioners in Kingdom of Saudi Arabia.
}

\author{
Bailoor Durgesh ${ }^{1}, \mathrm{Al}$ Shamrani Ammar ${ }^{2}$ \\ ${ }^{1}$ Professor Of Oral Radiology And Head Of PBL Systems \\ ${ }^{2}$ Assistant Professor And Vice-Dean Administrationfaculty Of Dentistry, University Of Taif. \\ Kingdom Of Saudi Arabia.
}

\begin{abstract}
:
Background: With strong medications and improved medical diagnosis and treatments, more and more dental patients will appear on dentists door step with severe medical compromise. This study has attempted to analyze the knowledge, attitudes and practices of the dentists and their involvement with medically compromised dental patients.

Methods: A total of 112 dental surgeons were randomly surveyed and response collected in structured oogle forms. The competency of dentist in the dental practice was assessed on 11 criteria mentioned in the results. The statistical analysis was done using the Decision Analyst 2.00@ (12) software .

Results: The most common medical emergency episodes reported were of vasovagal attack and the poglycemia and in contrast, the clinical conditions of Stroke, adverse reaction to LA and Anginal episode which were least reported. Feedback was predominantly from Government institutions. In areas of mal-practice insurance, standardized case history and their Basic Life support[ BLS] training dental practitioners from Government fared much better percentage wise .

Conclusion: The primary gaps identified in the dentist training were; improper vigilance for expiry medicines, lack of telephonic link with physician who can assist in the medical emergency and the inability to give intramuscular /intra-venous injections. This study highlights need to identify strengths and weakness in the curriculum of dentists and need to modify the medical risk assessment competency in the dental practitioners of today in the kingdom. A sense of frustration was also noted in the dentists in the kingdom about oversupply of dentists from the local universities.
\end{abstract}

Keywords: Education, Dental, Life support care, Basic Life support(BLS); Medical risk; Saudi Arabia; Dentist frustration.

\section{Introduction}

The dental practitioners form the first line of defense against the oral diseases management in the kingdom. Saudi Arabia has both Government and Private Universities training the dental surgeons. These programs are in a state of evolution and this study attempts to identify the strengths and weaknesses of the dentist's training in domain of medical risk assessment. The cardiopulmonary resuscitation is rarely used in dental clinic, but with increasing incidence of medical complexity in the general population, its role in saving critical patient lives becomes very important.

The Basic Life Support [BLS] training means immediate recognition of clinical problems of ventilation and circulation, during the process of cardiac or respiratory failure. Phillips and Nolan (1). Quality health care means increased number of dental patients with medical risk will be seen in the dental practice environment. Haas D (2) .This raises the possibility of increased frequency of emergencies in the dental clinic and dental hospital environment. Hendler and Rose (3).

The dependent variable in this study is the dentist's competency to manage the medically complex dental patients and the independent variables are - audit of expired medicines, direct communication with physician, routine use of intramuscular or intravenous injections, use of medical release form, malpractice insurance, BLS training, Use of Adrenaline, Standardized case history format, use of oxygen cylinder, rational use of antibiotic prophylaxis and use of four handed dentistry - trained assistant, giving obesity related advice to patients.

Different methods of data collection have been used to assess the level of training available for a professional population. However, a retrospective questionnaire is a reasonable and practical way to gather enough data over a sufficiently long period of time to produce meaningful information. Atherton et al (4). 
Medical Risk Assessment In Dental Patients : A Cross Sectional KAP [Knowledge, Attitude ....

Review of recent literature from Saudi Arabia depicts that very little scientific data is present which tells us about the awareness, knowledge and attitude of the dental practitioners towards the medical risk assessment in the dental clinic. Hence this nation-wide survey study was conducted. It is hoped that this data will help to improve the training of future dental graduates in schools of dentistry through strengthening of curriculum once the weak realms of knowledge and gaps in training are discovered.

\section{Materials and methods :}

A randomized cross sectional study using a structured questionnaire with eleven independent variables which in turn effected the dependent variable of clinical competency in treatment of Medically complex patients in dentists. An anonymous internet based circulation of structured questionnaire was done and all the dentists were also contacted subsequently over mobile phone to encourage them to answer quickly. Out of total 150 dental surgeons contacted 112 responses were found complete and valid others had to be rejected for incomplete or incoherent answers. ( $74.66 \%$ of survey instruments accepted after audit) A software Decision Analyst 2.00 (12) was utilized to calculate the ' $Z$ ' score.

2.1 Study population and design : The universe was the dental practitioners population of Kingdom of Saudi Arabia and the design was cross sectional, randomized. The hypothesis question stated was 'The dentists training was not adequate; based on eleven independent variables' The structured questionnaire and the researcher not knowing about the identity of the dentist [blinding] was a good model for research.

The questionnaires were sent via Google forms to dentists in different parts of the kingdom. All the data collected was entered in Excel sheet and analyzed.

2.2 Instrument and data collection : The structured survey instrument was utilized for data collection and a $75 \%$ of the dentists responded .

2.3 Data analysis: The Microsoft office excel sheet 2007 was used for preliminary statistical analysis . This revealed candid information about the attitudes and awareness of the different dentists in the kingdom. These are tabulated in the tables no 1 , no 2 and no 3 . The ' $Z$ ' value is used evaluate statistically the differences between the Male and female dentists and also private dental school and government dental school dentists.

\section{Results}

3.1 Basic Analysis : A total of 112 dental surgeons were surveyed in depth for basic information [table 1], The figure 1. Shows the graph of 11 item analysis of the BLS steps being practiced by these dentists , figure No. 2 : This shows an item analysis of 16 processes actually done successfully in dental clinic.

To be inserted.

Table no. 1

Figure no. 1

Table no.2

\subsection{Statistical Analysis}

The statistical analysis was done using Decision Analyst $2.00{ }^{12}$. The eleven attributes shown in figure no 2, have been analyzed for two groups of data. First the comparison between the male and female dentists, and second between the government and private dentists .

Insert here

Table no 3.

Table no 4.

\section{Discussion}

On examination of the table no. 3 of our study it is apparent that the percentage of statistical difference of the use of audit of expired medicines, use of adrenaline and regular use of oxygen cylinder all showed a very weak $\mathrm{Z}$ value. These were identified as the gaps of training in the dentist. This compared well with study of Atherton et al $(4,5)$

The classical article by Atherton et al $(4,5)$ on medical emergencies in general dental practice is the study in which about 1500 dental practitioners and about 1000 in Wales and 500 in Scotland were surveyed and the results were quite enlightening. Atherton showed that basic drugs of emergency care were available in $90 \%$ of the respondents. This compares with $24 \%$ Government dentist and $21 \%$ Private college dentists in our study The cardiopulmonary resuscitation (CPR) was carried out in management of 1.1 to $1.4 \%$ of the events in the general practice not related to GA. 
Medical Risk Assessment In Dental Patients : A Cross Sectional KAP [Knowledge, Attitude ....

Our study reflects the conclusion of Chapman's (6) related work in Australia which also throws a veritable light on the state of affairs in the Australian dental landscape as regards to the choice of emergency drugs and equipment. He polled 1250 respondents dental practitioners and found that 1 in 7 ( $14 \%$ ) had to resuscitate a patient in their dental clinic. This figure appears to be ten times the data obtained from Atherton's work. So obviously some geographic differences are bound to appear in different parts of the world. In Saudi Arabia we found our dentists both of government and private colleges observed the use of oxygen cylinders in practice and the difference statistically between them was weak.

This dentist study depicts that weak $\mathrm{Z}$ values on use of intramuscular and intravenous medications and use of oxygen cylinder, which means we share the opinions of Shearer J et al (7), who expressed some very strong opinions about allowing the dentists to use the art of conscious sedation and anxiety control. They opined that they did not feel that it was appropriate for the dentists to use it in any form, even the simplest type of conscious sedation. They (7) were probably concerned about their ability to manage emergencies as and when they occurred.

In our series $24 \%$ of the Government interns and $53 \%$ of the Private interns took the training for Basic life support BLS and displayed their certificates.

Shearer J et al (7) had another serious concern, that the types of trainings available in the British Isles were very varied; consisting of short term courses and in depth courses which may lead to Masters in sedation [M.Sc], available in London. Considering this variation of training even in an established academic environment of UK, it is easy to see why Shearer et al (7) not very great champions of allowing the dental surgeons into conscious sedation and advanced emergency treatment area, without proper competency training. In the kingdom only one level of BLS certificate given by the red cross, was available.

Coplans and Green (8) agree with the work of Shearer J et al (7) that the use of conscious dentistry is fraught with the risks that are tangible, in terms of medical emergencies in the clinic.

The findings of this series of dentists data agrees with that of Robertson and Rothman (9) , who have analyzed the awareness of medical emergencies in the dental office in the dentist population. They analyzed 182 dentist responses to come to their conclusions. In this study 56\% reported receiving the Basic Life Support [BLS] and 34\% said that medical emergencies were seen and managed by them. $2 \%$ of these dentists responded positive for discovering angioedema in their practice and 5\% had seen Angina on their dental chair. An interesting fact that came from this study was that $24 \%$ preferred pre-medication in the dental patients with known history of Epilepsy. About half the number of Government dentists and one third of the private dentists in our series treated emergencies using adrenaline routinely.

O' Hallaran(10) has given a clear map of the clinical approach in his discussion and stated that the systems review, medical history and physical examination, including the body mass index (BMI), should make the dentist determine the medical risk, then grade the patient as per the ASA American Society of Anesthesiologists (ASA) Physical Status Classification System. It is generally agreed upon that ASA1 and the ASA 2 are treated in the dental clinic with least complications.

Maisa $\mathrm{O}$ et al (11) have studied the preparedness of the private dental clinics in Jeddah and found that deficiency in personnel training, availability of drugs, and emergency equipment in the surveyed dental clinics.

Our study was predominantly done with data from the western parts of the kingdom and we report an interesting study by Alhamad et al (13) (12) who have worked in the eastern province of Saudi Arabia. Their findings of vasovagal attack and hypogycemia being the most commonly encountered complications is shared completely by our study.

They (13) (12) further opined that medical emergency situations were common in dental clinics, but a considerable proportion of dentists did not feel at ease to handle medical emergency conditions.

The level of BLS training in kingdom is available at only one level, that is provided for three days by the Red Cross. The facilities of Government and Private clinics compared well with each other. In this study more dentists from government gave feedback as compared with private dental colleges.

In the remarks section which was last blank given to dentists 99 out of 112 felt that there were too many dentists graduating from the dental schools in the kingdom and that already a glut of dentists was causing frustration in the kingdom of Saudi Arabia. Arab News (14). (13)

\section{Conclusion}

From the above study these conclusions may be summarized.

1. The Use of trained nurse, a medico-legal release form and a standardized case history form were well documented in the Government dental schools and very much less in the private dental schools, hence very strong statistical differences in their occurrence.

2. The use of Oxygen cylinder and antibiotic prophylaxis were more in the government facilities, both in terms of availability, observance and usage. 
3. The malpractice insurance is a mandatory for all practitioners hence we found both government and private interns had covered themselves with it and between $24.19 \%$ to $53.7 \%$.

4. The medical emergency cabinet was audited and checked by $21.4 \%$ to $24.19 \%$ dentists in the kingdom and through training, this was perceived as a gap and needs to be improved.

5. It is the finding of this study that BLS, Malpractice insurance and the standardized Case history form should be made mandatory if the medical risk of dental patients need to be improved dramatically in the coming years. The training gaps of dentists in medical risk domain may vary with the regions of kingdom surveyed hence more studies must be attempted and specific gaps identified and filled as a part of designing their curriculum in the coming years.

6. A high percentage of dentists were frustrated [88.39\%] due to inability to get jobs attributed to oversupply of dentists from the local universities in the Saudi Arabia. Arab news (14). (13)

Conflict of interest: The author has no conflict of interest to declare

\section{References}

[1]. Phillips PS, Nolan JP. Training in basic and advanced life support in UK medical schools: Questionnaire survey. BMJ. 2001 Jul 7;323(7303):22-3. dx.doi.org/10.1136/bmj.323.7303.22

[2]. Haas D: Automated external defibrillator use in dentistry. J Can Dent Assoc 2007 (73) :289, doi:10.1016/j.denabs.2007.12.011

[3]. Barry H. Hendler, Louis F. Rose. Common medical emergencies: a dilemma in dental education The Journal of the American Dental Association 1975 volume 91 issue 3 on pages 575 to 582 dx.doi.org/10.14219/jada.archive.1975.0427 Atherton GJ, McCaul JA, Williams SA. Medical emergencies in general dental practice in Great Britain. Part 1: their prevalence over a 10-year period. Br Dent J 1999;186(2):72-9. dx.doi.org/10.1038/sj.bdj.4800023a

[4]. Atherton GJ, McCaul JA, Williams SA. Medical Emergencies in general dental practice in Great Britain Part 2:Drugs and equipment possessed by GDPs and used in the management of emergencies. British Dental Journal volume 186 issue 3 on pages 125 to 130 dx.doi.org/10.1038/sj.bdj. 4800040

[5]. Chapman PJ. Medical emergencies in dental practice and choice of emergency drugs and equipment: a survey of Australian dentists. Aust Dent J. 1997 Apr;42(2):103-8. dx.doi.org/10.1111/j.1834-7819.1997.tb00104.x

[6]. J Shearer, K E Wilson \& N M Girdler .A survey of the opinions of consultant anaesthetists in Scotland of sedation carried out by dentists British Dental Journal .2004 196, 93 - 98 Published online: 24 January 2004 . dx.doi.org/10.1038/sj.bdj.4810901

[7]. M. P. Coplans and R. A. Green. Anaesthesia and sedation in dentistry: Edited by Pp. 421, illustrated. 1983. Oxford, Elsevier. doi:10.1016/0300-5712(84)90076-9

[8]. Roberson JB(1), Rothman CM. Call 9-1-1 now and start treatment. Dent Today. 2009 ;28(5):108, 110-1. PMID :19485019

[9]. O'Halloran Michael. The use of anaesthetic agents to provide anxiolysis and sedation in dentistry and oral surgery- Australas Med J. 2013; 6(12): 713-718.

Published online 2013 Dec 31. dx.doi.org/10.4066/amj.2013.1836

[10]. 11. Maisa O. Al-Sebaei, Moayyad A. Alkayyal, Abdulelah H. Alsulimani, Othman S. Alsulaimani, Weam T. Habib. The preparedness of private dental offices and polyclinics for medical emergencies. A survey in Western Saudi Arabia. Saudi Med J 2015; Vol. 36 (3): 335-340 doi: 10.15537/smj.2015.3.10047

[11]. 12. WWW. Decisionanalyst.com. Version 2.00 Free download from this site. - A free statistical software for basic statistics.

[12]. 13. Alhamad M, Alnahwi T, Alshayeb H, Alzayer A, Aldawood O, Almarzouq A, Nazir MA. Medical emergencies encountered in dental clinics: A study from the Eastern Province of Saudi Arabia. J Fam Community Med 2015;22:175-9 DOI: 10.4103/22308229.163038 .

[13]. 14. Jobless Saudi dentist burns certificate.ARAB NEWS | Published — Tuesday 17 May 2016: Muhana Saud burns his dentist certificate in frustration - http://www.arabnews.com/news/jobless-saudi-dentist-burns-certificate

Table No .1

This table shows the basic demographics of the sample of 112 dentists who responded. They were predominantly from Government dental schools and Male. $33 \%$ of the responses came from the Western region

\begin{tabular}{|c|c|c|c|c|}
\hline Sex & Male & Female & & Remarks \\
\hline Data & $90[80.35 \%]$ & $22[19.64 \%]$ & & $\begin{array}{r}\text { Predominantly } \\
\text { male }\end{array}$ \\
\hline \multirow{2}{*}{$\begin{array}{r}\text { Type } \\
\text { of } \\
\text { dental } \\
\text { school } \\
\end{array}$} & Government & Private & & \\
\hline & $85[75.89 \%]$ & $27[24.10 \%]$ & & $\begin{array}{r}\text { Predominantly } \\
\text { Government }\end{array}$ \\
\hline \multirow{5}{*}{$\begin{array}{l}\text { Region } \\
\text { of the } \\
\text { dental } \\
\text { school }\end{array}$} & North & 20 & $17.85 \%$ & \\
\hline & South & 18 & $16.07 \%$ & \\
\hline & West & 38 & $33.92 \%$ & $\begin{array}{l}\text { Sample was } \\
\text { weighted to } \\
\text { the } \begin{array}{l}\text { west } \\
\text { region }\end{array}\end{array}$ \\
\hline & East & 19 & $16.96 \%$ & \\
\hline & Middle & 17 & $15.17 \%$ & \\
\hline
\end{tabular}


Medical Risk Assessment In Dental Patients : A Cross Sectional KAP [Knowledge, Attitude ....

Foot note: This nation wide study of Saudi Arabia depicts the sex distribution, government vs Private

distribution and the regional distribution of the sampled dentists. Bailoor and Al-Shamrani 2016

\section{Figure No. 1}

This depicts the fact that use of trained nurse, case history format, consent form and display of basic life support certificate all were seen uniformly in all clinics; whereas the neglected areas were the lack of obesity related advise, negative attitude towards the voluntary work, doing extracurricular work and sports, and the ability to give Intra venous and intramuscular injections. The thirteen characteristics analyzed other issues like expired meds audit, direct phone line to physician and use of antibiotic guidelines were in the range of 20 to 50 percent.

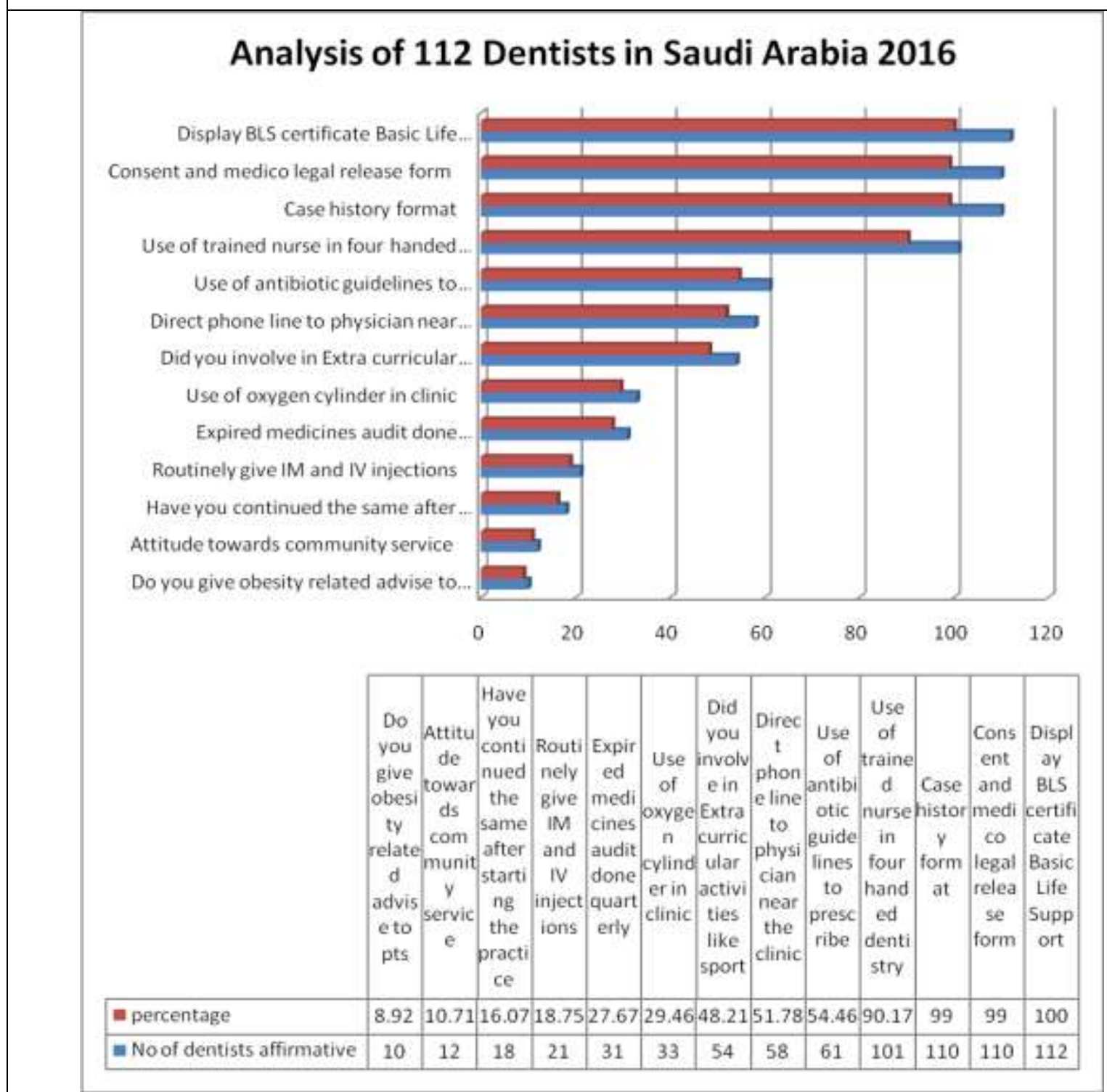

Foot note: Giving of Obesity related advise, and attitude towards the community service was the worst numerically polled.

Bailoor and Al Shamrani 2016.

\section{Table No. 2}

This shows an item analysis of medical risk and the 16 processes actually done successfully by a set of 112 dental surgeons surveyed in the kingdom of Saudi Arabia. The three most common and successfully managed in this series was the Syncope, bleeding episodes and use of prophylactic antibiotics ; the rare cut off point used was 4 percent and it constituted of anginal attacks, epileptic fits, anaphylactic attacke, Post road traffic accident, renal dialysis, coronary attack, reaction to LA, Stroke and hyperglycemic shock. Showing the incidents analyzed in the 112 dental clinics categorized into Common $=50-100 \%$; Can Happen $=10-49 \%$; Rare $=0-9 \%$, This will help the dentists to be prepared for the common as well as the rare. Bailoor and Al Shamrani 2016. 
Medical Risk Assessment In Dental Patients : A Cross Sectional KAP [Knowledge, Attitude ....

\begin{tabular}{|c|c|c|c|}
\hline $\begin{array}{r}\text { Medical } \\
\text { Emergency / Risk } \\
\text { observed }\end{array}$ & Number & Percentage & $\begin{array}{rr}\text { How } & \text { often } \\
& \text { encountered }\end{array}$ \\
\hline Syncope & 110 & 98.2 & Common \\
\hline Bleeding episodes & 90 & 80.35 & Common \\
\hline $\begin{array}{l}\text { Identifying need } \\
\text { for antiobiotic } \\
\\
\text { prophylaxis }\end{array}$ & 85 & 75.89 & Common \\
\hline $\begin{array}{r}\text { Medical } \\
\text { compromise of } \\
\text { multi-system } \\
\text { encountered }\end{array}$ & 51 & 45.53 & Can Happen \\
\hline $\begin{array}{r}\text { Asthamatic attack } \\
\text { on dental chair }\end{array}$ & 15 & 13.39 & Can Happen \\
\hline $\begin{array}{l}\text { Angio-edema and } \\
\text { allergic reactions }\end{array}$ & 14 & 12.5 & Can Happen \\
\hline $\begin{array}{r}\text { Hypoglycemic } \\
\text { Shock }\end{array}$ & 13 & 11.6 & Can Happen \\
\hline $\begin{array}{lr}\text { Anginal } & \text { episodes } \\
\text { during } & \begin{array}{r}\text { dental } \\
\text { treatment }\end{array} \\
\end{array}$ & 5 & 4 & Rare \\
\hline $\begin{array}{l}\text { Epileptic attach on } \\
\text { dental chair }\end{array}$ & 5 & 4 & Rare \\
\hline $\begin{array}{r}\text { Anaphylaxis in the } \\
\text { dental clinic }\end{array}$ & 5 & 4 & Rare \\
\hline $\begin{array}{r}\text { Road } r \text { traffic } \\
\text { accident and Post } \\
\text { RTA shock }\end{array}$ & 4 & 3,5 & Rare \\
\hline $\begin{array}{rr}\text { Renal } & \text { dialysis } \\
\text { patiients coming as } \\
\text { OPD dental }\end{array}$ & 4 & 3.5 & Rare \\
\hline $\begin{array}{lr}\text { Coronary } & \text { Attack } \\
\text { during } & \text { the } \\
& \text { treatment } \\
\end{array}$ & 4 & 3.5 & Rare \\
\hline $\begin{array}{l}\text { Adverse reaction to } \\
\text { Local Anesthesia } \\
\text { during } \\
\text { extraction/biopsy }\end{array}$ & 3 & 2.6 & Rare \\
\hline \multicolumn{4}{|c|}{$\begin{array}{r}\text { Foot Note : Incidents occurring in 50-100 percentage were shown as common , } 10-49 \text { percentage were shown to } \\
\text { as Can Happen and below } 9 \text { percentage were deemed to be rare. Bailoor and Al Shamrani } 2016\end{array}$} \\
\hline
\end{tabular}

\section{Figure No 2:}

Figure showing graphically the different medical emergency episodes in the 112 dental clinics of Saudi Arabia as per this cross sectional study. Bailoor and Al Shamarani 2016 


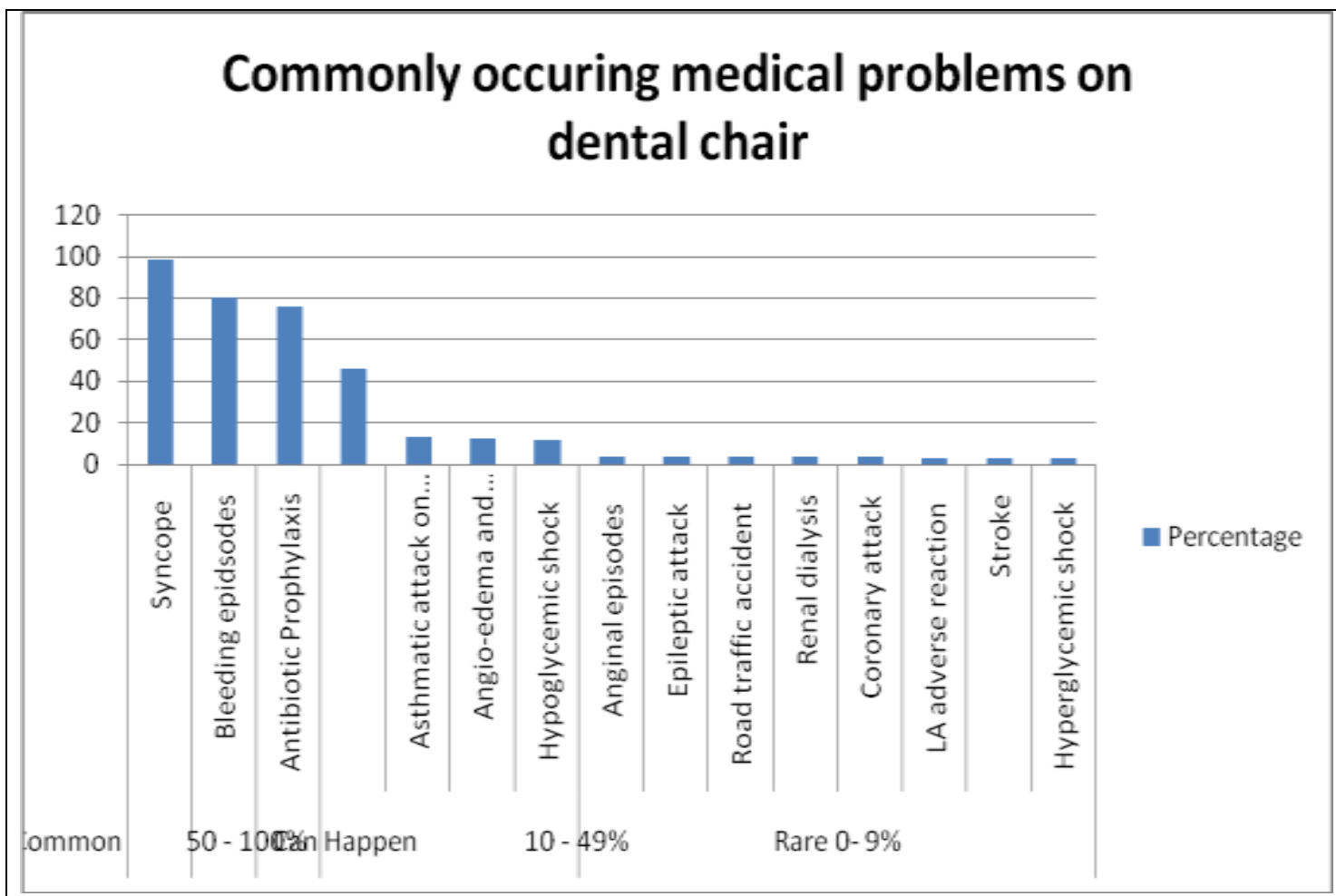

Foot note: The three emergencies predominated in this series the syncope[ vaso-vagal attack ], bleeding episodes, and diagnosis of conditions that require antibiotic prophylaxis- Bailoor and Al Shamrani

2016

\section{Table No. 3:}

Shows the differences between the Male and Female dentists in eleven factor item analysis . the software Decision Analyst was used to determine the statistical significance between the males and females.

Items, use of medico-legal release form and usage of standardized history format showed a strong difference between the males and the females Items, Regular audit for expired meds, Adrenaline use, and routine use of assistant and four handed dentistry showed no significant difference and all other items showed a weak difference in applications of these criteria in the routine dental practice in the domain of medical risk assessment.

\begin{tabular}{|c|c|c|c|c|c|c|}
\hline $\begin{array}{c}\text { Crite } \\
\text { ria }\end{array}$ & $\begin{array}{c}\mathrm{Nu} \\
\text { me } \\
\text { ric } \\
\text { al } \\
\mathrm{M} \\
\text { ale }\end{array}$ & $\begin{array}{c}\mathrm{Nu} \\
\text { me } \\
\text { ric } \\
\text { al } \\
\mathrm{Fe} \\
\text { ma } \\
\text { le }\end{array}$ & $\begin{array}{l}0 \\
1 \\
a \\
1 \\
e\end{array}$ & $\begin{array}{r}\% \\
\mathrm{~F} \\
\mathrm{e} \\
\mathrm{m} \\
\mathrm{a} \\
1 \\
\mathrm{e}\end{array}$ & $\begin{array}{l}\mathrm{P} \\
\mathrm{O} \\
\mathrm{S} \\
\mathrm{D}\end{array}$ & $\begin{array}{r}\text { Diff } \\
\text { eren } \\
\text { ce } \\
\text { Sign } \\
\text { ifica } \\
\text { nce }\end{array}$ \\
\hline $\begin{array}{r}\text { Obes } \\
\text { ity } \\
\text { relat } \\
\text { ed } \\
\text { advis } \\
\mathrm{e} \\
\end{array}$ & 11 & 5 & 2 & $\begin{array}{l}7 \\
1\end{array}$ & $\begin{array}{r}4 \\
5 \\
9 \\
9 \\
2 \\
\% \\
\end{array}$ & $\begin{array}{c}\text { Wea } \\
\mathrm{k}\end{array}$ \\
\hline $\begin{array}{r}\text { Com } \\
\text { muni } \\
\text { ty } \\
\text { servi } \\
\text { ce } \\
\text { attitu } \\
\text { de }\end{array}$ & 46 & 18 & $\begin{array}{l}1 \\
1\end{array}$ & $\begin{array}{l}\dot{8} \\
1\end{array}$ & $\begin{array}{l}9 \\
7 \\
8 \\
8 \\
4 \\
\%\end{array}$ & $\begin{array}{r}\text { Stro } \\
\text { ng }\end{array}$ \\
\hline $\begin{array}{r}\text { Have } \\
\text { you } \\
\text { conti } \\
\text { nued } \\
\text { the } \\
\text { same }\end{array}$ & 31 & 7 & $\begin{array}{l}3 \\
4\end{array}$ & $\begin{array}{l}3 \\
1 \\
8 \\
8 \\
1\end{array}$ & $\begin{array}{r}2 \\
3 \\
2 \\
3 \\
\% \\
\end{array}$ & $\begin{array}{c}\text { Wea } \\
\mathrm{k}\end{array}$ \\
\hline Rou & 81 & 21 & 9 & 9 & 5 & Mod \\
\hline
\end{tabular}


Medical Risk Assessment In Dental Patients : A Cross Sectional KAP [Knowledge, Attitude ....

\begin{tabular}{|c|c|c|c|c|c|c|}
\hline $\begin{array}{r}\text { ntine } \\
\text { ly } \\
\text { give } \\
\text { IM } \\
\text { and } \\
\text { IV } \\
\text { injec } \\
\text { tions }\end{array}$ & & & 0 & $\begin{array}{l}5 \\
4 \\
4 \\
5\end{array}$ & $\begin{array}{c}3 \\
\\
8 \\
5 \\
\%\end{array}$ & erate \\
\hline $\begin{array}{r}\text { Expi } \\
\text { red } \\
\text { medi } \\
\text { cine } \\
\text { audit } \\
\text { qtrly }\end{array}$ & 88 & 22 & $\begin{array}{l}9 \\
7 \\
7 \\
7\end{array}$ & $\begin{array}{l}1 \\
0 \\
0\end{array}$ & $\begin{array}{c}5 \\
2 \\
4 \\
4 \\
5 \\
\%\end{array}$ & $\begin{array}{l}\text { Mod } \\
\text { erate }\end{array}$ \\
\hline $\begin{array}{r}\text { Use } \\
\text { of } \\
\text { oxyg } \\
\text { en } \\
\text { cylin } \\
\text { der } \\
\text { in } \\
\text { clini } \\
\text { c }\end{array}$ & 15 & 17 & $\begin{array}{l}1 \\
6\end{array}$ & $\begin{array}{l}7 \\
7 \\
2 \\
7\end{array}$ & $\begin{array}{c}9 \\
9 \\
9 \\
9 \\
6 \\
\%\end{array}$ & $\begin{array}{r}\text { Stro } \\
\text { ng }\end{array}$ \\
\hline $\begin{array}{r}\text { Do } \\
\text { you } \\
\text { do } \\
\text { extra } \\
\text { curri } \\
\text { cular } \\
\text {-like } \\
\text { sport } \\
\mathrm{s} \\
\end{array}$ & 9 & 3 & $\begin{array}{l}1 \\
0\end{array}$ & $\begin{array}{l}1 \\
3 \\
6 \\
6 \\
3\end{array}$ & $\begin{array}{c}4 \\
5 \\
3 \\
5 \\
5 \\
\%\end{array}$ & $\begin{array}{r}\text { Wea } \\
\mathrm{k}\end{array}$ \\
\hline $\begin{array}{r}\text { Dire } \\
\mathrm{ct} \\
\text { phon } \\
\mathrm{e} \\
\text { line } \\
\text { to } \\
\text { phys } \\
\text { ician }\end{array}$ & 14 & 22 & $\begin{array}{l}2 \\
2 \\
5 \\
8\end{array}$ & $\begin{array}{l}1 \\
0 \\
0\end{array}$ & $\begin{array}{c}1 \\
0 \\
0 \\
\%\end{array}$ & $\begin{array}{r}\text { Stro } \\
\text { ng }\end{array}$ \\
\hline $\begin{array}{r}\text { dIag } \\
\text { nose } \\
\text { the } \\
\text { need } \\
\text { for } \\
\text { antib } \\
\text { iotic } \\
\text { prop } \\
\text { hyla } \\
\text { xis }\end{array}$ & 24 & 20 & $\begin{array}{l}3 \\
8 \\
7\end{array}$ & $\begin{array}{l}7 \\
1 \\
4 \\
4 \\
2\end{array}$ & $\begin{array}{l}9 \\
6 \\
8 \\
8 \\
4 \\
\%\end{array}$ & $\begin{array}{r}\text { Stro } \\
\text { ng }\end{array}$ \\
\hline $\begin{array}{r}\text { Certi } \\
\text { fied } \\
\text { nurs } \\
\mathrm{e} \quad \text { in } \\
4 \\
\text { hand } \\
\text { ed } \\
\text { work }\end{array}$ & 28 & 20 & $\begin{array}{l}4 \\
5 \\
1 \\
6\end{array}$ & $\begin{array}{l}7 \\
1 \\
4 \\
4\end{array}$ & $\begin{array}{l}8 \\
9 \\
5 \\
5 \\
4 \\
\%\end{array}$ & $\begin{array}{r}\text { Stro } \\
\text { ng }\end{array}$ \\
\hline $\begin{array}{r}\text { Stan } \\
\text { dard } \\
\text { case } \\
\text { form } \\
\text { at }\end{array}$ & 20 & 8 & $\begin{array}{l}3 \\
2 \\
2 \\
5\end{array}$ & $\begin{array}{l}2 \\
8 \\
5 \\
5 \\
7\end{array}$ & $\begin{array}{l}2 \\
0 \\
. \\
8 \\
7 \\
\% \\
\end{array}$ & $\begin{array}{c}\text { Wea } \\
\text { k }\end{array}$ \\
\hline $\begin{array}{r}\text { Cons } \\
\text { ent } \\
\text { and } \\
\text { medi } \\
\text { co } \\
\text { relea } \\
\text { se }\end{array}$ & 89 & 21 & 8 & $\begin{array}{l}9 \\
5 \\
4 \\
4 \\
5\end{array}$ & $\begin{array}{r}7 \\
3 \\
8 \\
8 \\
3 \\
\%\end{array}$ & $\begin{array}{r}\text { Stro } \\
\text { ng }\end{array}$ \\
\hline
\end{tabular}


Medical Risk Assessment In Dental Patients : A Cross Sectional KAP [Knowledge, Attitude ....

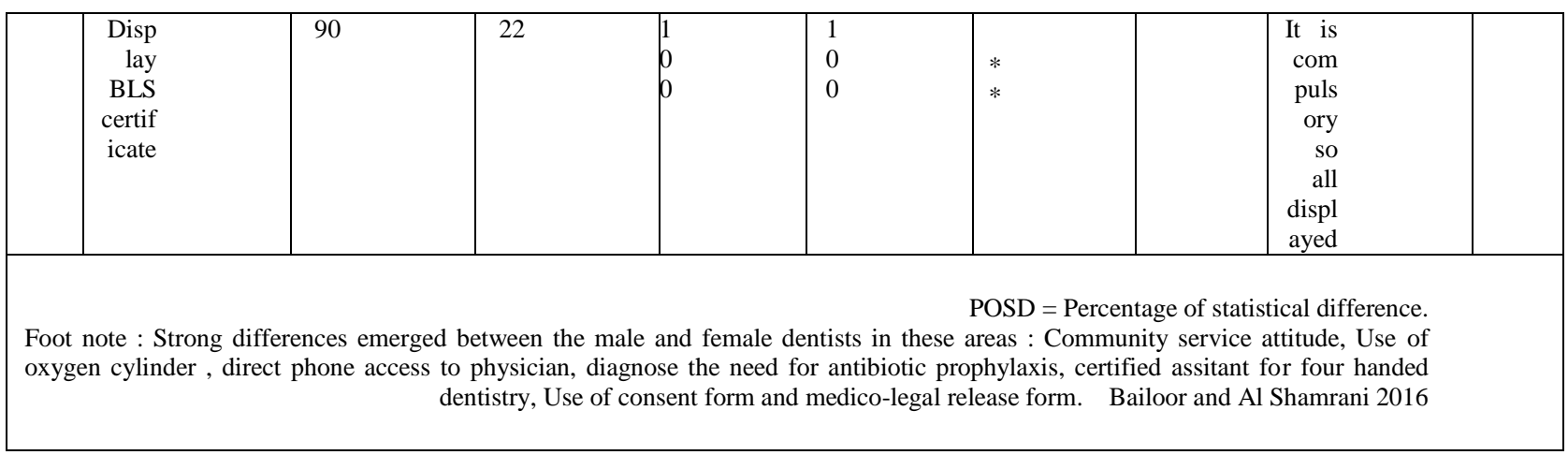

\section{Table no.4:}

s table shows the eleven item analysis between the Dentists working for Government and Private. Certain ns showed a significant statistical difference. The weakest difference in Government [85] and Private[27]

\begin{tabular}{|c|c|c|c|c|c|}
\hline & \multicolumn{5}{|c|}{ Dentists emerged in community service and obesity related medical advice } \\
\hline $\begin{array}{c}\text { Crite } \\
\text { ria }\end{array}$ & $\begin{array}{r}\mathrm{Nu} \\
\text { mer } \\
\text { ical } \\
\text { Go } \\
\text { vt }\end{array}$ & $\begin{array}{c}\text { Nume } \\
\text { rical } \\
\text { Privat } \\
\text { e }\end{array}$ & $\begin{array}{c}\% \\
\text { Pri } \\
\text { va } \\
\text { te }\end{array}$ & $\begin{array}{r}Z \\
\text { val } \\
\text { ue }\end{array}$ & $\begin{array}{r}\mathrm{Re} \\
\mathrm{ma} \\
\mathrm{rks} \\
\mathrm{ab} \\
\text { out } \\
\text { dif } \\
\text { fer } \\
\text { enc } \\
\mathrm{e}\end{array}$ \\
\hline $\begin{array}{r}\text { Obes } \\
\text { ity } \\
\text { relat } \\
\text { ed } \\
\text { advi } \\
\text { se } \\
\end{array}$ & 15 & 6 & $\begin{array}{r}21 \\
.4 \\
2\end{array}$ & $\begin{array}{r}0.4 \\
86\end{array}$ & $\begin{array}{l}\mathrm{We} \\
\mathrm{ak}\end{array}$ \\
\hline $\begin{array}{r}\text { Attit } \\
\text { ude } \\
\text { towa } \\
\text { rds } \\
\text { com } \\
\text { muni } \\
\text { ty } \\
\text { servi } \\
\text { ce }\end{array}$ & 30 & 10 & $\begin{array}{r}35 \\
.7 \\
1\end{array}$ & $\begin{array}{r}0.5 \\
48\end{array}$ & $\begin{array}{r}\mathrm{We} \\
\text { ak }\end{array}$ \\
\hline $\begin{array}{r}\text { Hav } \\
\mathrm{e} \\
\text { you } \\
\text { conti } \\
\text { nued } \\
\text { the } \\
\text { same } \\
\text { after } \\
\text { starti } \\
\text { ng } \\
\text { pract } \\
\text { ice }\end{array}$ & 9 & 7 & 25 & $\begin{array}{r}0.8 \\
88\end{array}$ & $\begin{array}{l}\text { Mo } \\
\text { der } \\
\text { ate }\end{array}$ \\
\hline $\begin{array}{r}\text { Rout } \\
\text { inely } \\
\text { give } \\
\text { im }\end{array}$ & 60 & 28 & $\begin{array}{r}10 \\
0\end{array}$ & $\begin{array}{r}0.9 \\
77\end{array}$ & $\begin{array}{l}\text { Mo } \\
\text { der } \\
\text { ate }\end{array}$ \\
\hline
\end{tabular}


Medical Risk Assessment In Dental Patients : A Cross Sectional KAP [Knowledge, Attitude ....

\begin{tabular}{|c|c|c|c|c|c|}
\hline $\begin{array}{r}\text { and } \\
\text { iv } \\
\text { injec } \\
\text { tions }\end{array}$ & & & & & \\
\hline $\begin{array}{r}\text { Expi } \\
\text { red } \\
\text { medi } \\
\text { cine } \\
\text { audit } \\
\text { done } \\
\text { quart } \\
\text { erly }\end{array}$ & 9 & 9 & $\begin{array}{r}32 \\
.1 \\
4\end{array}$ & $\begin{array}{r}1.1 \\
34\end{array}$ & $\begin{array}{r}\text { Str } \\
\text { on } \\
\mathrm{g}\end{array}$ \\
\hline $\begin{array}{c}\text { Oxy } \\
\text { gen } \\
\text { cylin } \\
\text { der } \\
\text { use }\end{array}$ & 15 & 15 & $\begin{array}{r}53 \\
.5 \\
7\end{array}$ & $\begin{array}{r}1.4 \\
91\end{array}$ & $\begin{array}{r}\text { Str } \\
\text { on } \\
\mathrm{g}\end{array}$ \\
\hline $\begin{array}{r}\text { Invo } \\
\text { lvem } \\
\text { ent } \\
\text { in } \\
\text { extra } \\
- \\
\text { curri } \\
\text { cular } \\
\text { activ } \\
\text { ities } \\
\text { like } \\
\text { sport }\end{array}$ & 28 & 20 & $\begin{array}{r}71 \\
.4 \\
2\end{array}$ & $\begin{array}{r}1.6 \\
23\end{array}$ & $\begin{array}{r}\text { Str } \\
\text { on } \\
\mathrm{g}\end{array}$ \\
\hline $\begin{array}{r}\text { Dire } \\
\text { ct } \\
\text { phon } \\
\mathrm{e} \\
\text { line } \\
\text { to } \\
\text { phys } \\
\text { ician }\end{array}$ & 14 & 6 & $\begin{array}{r}21 \\
.4 \\
2\end{array}$ & $\begin{array}{r}0.4 \\
86\end{array}$ & $\begin{array}{r}\mathrm{We} \\
\text { ak }\end{array}$ \\
\hline $\begin{array}{r}\text { Diag } \\
\text { nose } \\
\text { the } \\
\text { need } \\
\text { for } \\
\text { antib } \\
\text { iotic } \\
\text { prop } \\
\text { hyla } \\
\text { xis }\end{array}$ & 60 & 18 & $\begin{array}{r}64 \\
.2 \\
8\end{array}$ & $\begin{array}{r}3.6 \\
79\end{array}$ & $\begin{array}{r}\text { Str } \\
\text { on } \\
\text { g }\end{array}$ \\
\hline $\begin{array}{r}\text { Cons } \\
\text { ent } \\
\text { and } \\
\text { medi } \\
\text { co } \\
\text { legal } \\
\text { relea } \\
\text { se }\end{array}$ & 62 & 10 & $\begin{array}{r}37 \\
.0 \\
3\end{array}$ & $\begin{array}{r}2.0 \\
51\end{array}$ & $\begin{array}{c}\text { Str } \\
\text { on } \\
\mathrm{g}\end{array}$ \\
\hline $\begin{array}{l}\text { Stan } \\
\text { dard } \\
\text { case } \\
\text { form }\end{array}$ & 62 & 8 & $\begin{array}{r}37 \\
.0 \\
3\end{array}$ & $\begin{array}{r}2.0 \\
51\end{array}$ & $\begin{array}{r}\text { Str } \\
\text { on } \\
\text { g }\end{array}$ \\
\hline
\end{tabular}


Medical Risk Assessment In Dental Patients : A Cross Sectional KAP [Knowledge, Attitude ....

\begin{tabular}{|c|c|c|c|c|c|}
\hline at & & & & & \\
\hline \begin{tabular}{|r} 
Certi \\
fied \\
assis \\
tant \\
4 \\
hand \\
ed \\
denti \\
stry
\end{tabular} & 60 & 11 & $\begin{array}{r}40 \\
.7 \\
4\end{array}$ & $\begin{array}{c}2.8 \\
05\end{array}$ & $\begin{array}{r}\text { Str } \\
\text { on } \\
\mathrm{g}\end{array}$ \\
\hline $\begin{array}{c}\text { Disp } \\
\text { lay } \\
\text { BLS } \\
\text { train } \\
\text { ing } \\
\text { certi } \\
\text { ficat } \\
\text { e }\end{array}$ & 85 & 27 & $\begin{array}{r}10 \\
0\end{array}$ & $* *$ & $\begin{array}{r}\text { Its } \\
\text { co } \\
\text { mp } \\
\text { uls } \\
\text { ory } \\
\text { in } \\
\text { the } \\
\text { kin } \\
\text { gd } \\
\text { om } \\
\text { so } \\
\text { all } \\
\text { dis } \\
\text { pla } \\
\text { y }\end{array}$ \\
\hline \multicolumn{6}{|c|}{$\begin{array}{l}\text { POSD }=\text { Percentage of statistical difference. } \\
\text { The following showed a strong difference between the government and private trained dentists : Expired } \\
\text { medicines audit, use of oxygen cylinder, extracurricular activities, diagnose the need for antibiotic } \\
\text { prophylaxis, Proper use of consent and medicolegal release, standardized case history format, and the } \\
\text { concept of four handed dentistry. Bailoor and Al Shamrani } 2016 .\end{array}$} \\
\hline
\end{tabular}

